\title{
PENGEMBANGAN SISTEM PEMBAWA ALBUMIN NANOPARTIKEL UNTUK SILIMARIN DAN KAJIAN SIFAT FISIK SERTA PROFIL PELEPASANNYA SECARA IN VITRO
}

\author{
Rini Ambarwati ${ }^{1}$, Heni Rachmawati ${ }^{2}$ \\ ${ }^{1}$ Universitas Pakuan, Bogor \\ ${ }_{2}^{2}$ Program Studi Magister Farmasetika, ITB, Bandung
}

\begin{abstract}
ABSTRAK
Silimarin merupakan senyawa flavonolignan yang berasal dari tumbuhan Silybum marianum (Asteraceae). Silimarin memiliki efek farmakologi sebagai antikanker dan hepatoprotektor, tetapi senyawa ini memiliki kelarutan yang rendah dalam air. Tujuan penelitian ini adalah mengembangkan formulasi silimarin dalam sistem pembawa nano dengan teknik desolvasi. Pembawa yang digunakan adalah serum albumin (bovine serum albumin/BSA). Kombinasi silimarin dalam BSA diharapkan dapat meningkatkan efikasi silimarin sebagai anti kanker karena permeabilitas BSA yang lebih baik pada sel kanker. Evaluasi standar terhadap nanopartikel silimarin-BSA meliputi ukuran dan distribusi ukuran partikel, zeta potensial, morfologi nanopartikel, kristalinitas, sifat termal, spektroskopi inframerah, efisiensi penjeratan serta profil pelepasan silimarin dari BSA nanopartikel pada 2 media berbeda $(\mathrm{HCl} 0,1 \mathrm{~N} \& \mathrm{PBS} \mathrm{pH} 7,4)$. Nanopartikel BSAsilimarin memiliki ukuran partikel 174,23 $\pm 13,94 \mathrm{~nm}$; distribusi ukuran partikel 0,185 \pm 0,052; efisiensi penjeratan 90,54 $\pm 0,098 \%$; loading capacity $30,18 \pm 0,036 \%$ dan zeta potensial -1,62 mV. Hasil analisis menggunakan DSC (differential scanning calorimetry), XRD (X-ray diffraction) dan spektroskopi inframerah menunjukan bahwa nanopartikel silimarin berhasil terenkapsulasi di dalam nanopartikel BSA, dan BSA-silimarin memiliki bentuk amorf. Setelah 1 jam uji pelepasan, terdapat sebanyak 21,89\% silimarin terlepas dalam $\mathrm{HCl} 0,1 \mathrm{~N}$ dan 54,84\% silimarin terlepas dalam PBS pH 7,4 sehingga dapat disimpulkan bahwa silimarin-BSA memiliki kelarutan yang baik dalam air. Oleh karena itu, perlu dilakukan pengujian lebih lanjut untuk mengkaji aktivitas serta perilaku silimarin-BSA in vivo untuk mengkonfirmasi data in vitro.
\end{abstract}

Kata kunci: Nanopartikel, Silimarin, BSA, Desolvasi, Albumin, Desolvating agent

\section{DEVELOPMENT OF SILIMARIN NANOPARTICLES CARRYING SYSTEM AND THE STUDY OF ITS PHYSICAL AND RELEASE PROFILE IN VITRO}

\begin{abstract}
Silimarin is a flavonolignan compound derived from Silybum marianum (Asteraceae) plant. Silimarin has a pharmacological effects as an anticancer and hepatoprotector substance, but the solubility of this compound is very low in the water. The purpose of this study was to develop a silimarin formulation in bovine serum albumin (BSA) nano-carrying system using desolvation technique. Since the BSA was more permeable in the cancer cell, the combination of silimarin in BSA was expected to increase the efficacy of silimarin as an anti-cancer. Standard evaluations of BSAsilimarin nanoparticles include particle size and distribution, potential zeta, morphology of nanoparticles, crystallinity, thermal properties, infrared spectroscopy and efficiency of trapping and silimarin release profiles of BSA nanoparticles on 2 different media $(\mathrm{HCl}$ $0.1 \mathrm{~N} \& \mathrm{PBS} \mathrm{pH}$ 7.4). BSA-silimarin nanoparticles have a particle size of $174.23 \pm 13.94$
\end{abstract}


$\mathrm{nm}$; particle size distribution $0.185 \pm 0.052$; efficiency of snares $90.54 \pm 0.098 \%$; loading capacity $30.18 \pm 0.036 \%$ and zeta potential $-1.62 \mathrm{mV}$. Results of analysis using DSC (differential scanning calorimetry), XRD (X-ray diffraction) and infrared spectroscopy showed that silimarin nanoparticles was successfully encapsulated in BSA nanoparticles whereas the BSA-silimarin have an amorphous form. After 1 hour of release test, there were $21.89 \%$ of silymarin released in $0.1 \mathrm{~N} \mathrm{HCl}$ and $54.84 \%$ of silymarin were released in PBS pH 7.4. It can be concluded that silimarin-BSA has good solubility in water. Therefore, further study is recommended to assess activity and in vivo behavior to confirm in vitro data.

Keywords: Nanoparticle, Silimarin, BSA, Desolvation, Albumine, Desolvating agent

\section{PENDAHULUAN}

Silimarin merupakan senyawa flavonolignan yang berasal dari tumbuhan Silybum marianum (Asteraceae) yang memiliki efek farmakologi sebagai antikanker, dan hepatoprotektor. Namun silimarin memiliki kelarutan yang rendah dalam air sekitar 0,04 mg/mL(Snima dkk., 2014). Berbagai upaya telah dilakukan untuk mengatasi masalah silimarin sebagai obat. Pada penelitian ini perbaikan ketersediaan hayati silimarin dilakukan dengan pendekatan sistem pembawa berbasis teknologi nano untuk mengenkapsulasi silimarin.

Berbagai sistem pembawa tersedia untuk proses enkapsulasi suatu obat yang bermasalah baik dalam formulasi maupun penghantarannya. Pada penelitian ini, dipilih protein, yaitu serum albumin. Dasar pertimbangan pemilihan albumin sebagai sistem pembawa adalah: inert, biokompatibel, relatif murah, mempunyai kemampuan membentuk nanopartikel dengan berbagai teknik, serta yang terpenting adalah kemampuan terpenetrasi lebih baik dan lebih banyak ke sel kanker dibandingkan sel normal. Sehingga, pemilihan albumin sebagai sistem pembawa silimarin diharapkan dapat meningkatkan efek antikanker dari silimarin (active targeting) (Yuan dkk., 2013).

Banyak terapi kanker secara konvensional masih menghadapi permasalahan yaitu akumulasi non spesifik dalam jaringan sel kanker. Dengan demikian, BSA sebagai pembawa diharapkan akan meningkatkan akumulasi silimarin ke sel kanker dan menekan distribusinya ke sel normal. Beberapa teknik pembuatan albumin nanopartikel, diantaranya teknik desolvasi dan emulsifikasi. Kekurangan dari metode emulsifikasi adalah penggunaan pelarut organik dan surfaktan sebagai penstabil sistem emulsi. Keduanya sangat sulit dihilangkan pada saat proses preparasi nanopartikel albumin (Langer, 2003). Maka dipilih menggunakan teknik desolvasi. Teknik desolvasi pada prinsipnya adalah mengubah kelarutan dari albumin di dalam air, dengan menambahkan faktor pendesolvasi. Kemudian ditambakan cross-link untuk meningkatkan rigiditas dari nanopartikel yang terbentuk.

Pada penelitian ini, akan dikembangkan sistem pembawa nanopartikel berbasis albumin untuk silimarin, dengan teknik desolvasi. Karakterisasi kemudian dilakukan pada nanopartikel yang dibuat.

\section{METODE PENELITIAN \\ Bahan}

Silimarin (Sigma Aldrich), BSA (Sigma Aldrich), $\mathrm{NaOH}$, Aseton, Glutaraldehid (Merck), $\mathrm{HCl}$, dapar fosfat 
pH 7,4 (komponen penyusun dapar : $\mathrm{KCl}$, $\mathrm{NaH}_{2} \mathrm{PO}_{4}, \mathrm{NaCl}$, dan $\mathrm{Na}_{2} \mathrm{HPO}_{4}$ )

\section{Alat}

Neraca Analitik (Mettler Toledo ${ }^{\circledR}$ XS205), pengaduk magnetic, stirrer, sonikator tipe bath (Krisbow ultrasonic Cleaner), alat analisis ukuran partikel dan zeta potensial (Delsa ${ }^{\mathrm{TM}}$ Nano C Particle Analyzer, Beckman Coulter), $\mathrm{pH}$ meter (Mettler Toledo ${ }^{\circledR}$ S20), Scanning Electron Microscope, Difraktometer sinar-X (Bruker, 8D Advance), jarum suntik $1 \mathrm{~mL}$ (Terumo), Spektrometer inframerah (FTIR-Shimadzu 8501), Spektrofotometer UV (Beckman DU 7500i), Vortex Mixer (IKA ${ }^{\circledR}$ MS 3 digital), alat mikrosentrifuga (Hsiang Tai), tabung mikrosentrifuga, kuvet disposable, dan alat gelas lain yang umum digunakan di laboratorium.

\section{Pembuatan Nanopartikel BSA mengandung Silimarin}

Formula optimum pada pembuatan nanopartikel BSA digunakan untuk membuat nanopartikel BSA yang mengandung silimarin. Berbagai jumLah silimarin $(7,5 ; 15$; dan $30 \mathrm{mg})$ ditambahkan ke larutan BSA, selanjutnya dilakukan proses yang sama dengan proses pembentukan nanopartikel albumin blanko.

\section{Karakterisasi Nanopartikel}

Karakterisasi fisika nanopartikel meliputi ukuran partikel, indeks polidispersitas, zeta potensial, morfologi nanopartikel, spetroskopi inframerah, analisis termal dengan DSC, dan difraktometri sinar-X.

Evaluasi Pelepasan Silimarin dari Nanopartikel BSA-Silimarin secara In vitro

Uji pelepasan silimarin dari nanopartikel BSA-silimarin dilakukan pada dua medium yang berbeda $\mathrm{PBS} \mathrm{pH}$ 7,4 (simulasi cairan darah) dan $\mathrm{HCl} 0,1 \mathrm{~N}$ (simulasi cairan lambung) pada suhu $37^{\circ} \mathrm{C}$, kecepatan pengadukan $100 \mathrm{rpm}$, selama 1 jam. Pada interval waktu yang ditentukan $(15 ; 30 ; 45 ; 60$ menit) diambil cuplikan sampel sebanyak $4 \mathrm{~mL}$, dan ditambahkan medium kembali sebanyak $4 \mathrm{~mL}$ agar volume mediumnya tetap. Kadar silimarin ditentukan dengan menggunakan Spektrofotometer UV pada panjang gelombang $288 \mathrm{~nm}$.

\section{HASIL DAN PEMBAHASAN}

Ukuran, Indeks Polidispersitas, Zeta Potensial, Efisiensi Penjeratan, dan Loading Capacity

Pada tahapan optimasi pemuatan silimarin ke dalam nanopartikel albumin, semakin banyak jumLah silimarin yang ditambahkan menghasilkan ukuran nanopartikel yang lebih besar. Silimarin yang ditambahkan sebanyak 7,$5 ; 15$;dan $30 \mathrm{mg}$ memberikan efisiensi penjeratan berturut-turut $90,39 \pm 0,157 ; 90,54 \pm$ 0,098; dan 89,75 $\pm 1,317 \%$. Loading Capacity nya secara berturut-turut adalah $18,076 \pm 0,030 ; 30,18 \pm 0,036 ;$ dan $44,88 \pm$ $0,666 \%$.

Tabel 1. Pengaruh JumLah Silimarin terhadap Karakteristik Nanopartikel BSAsilimarin

\begin{tabular}{|c|c|c|c|c|c|}
\hline $\begin{array}{c}\text { JumLah } \\
\text { Zat Aktif } \\
(\mathbf{m g})\end{array}$ & $\begin{array}{c}\text { Ukuran } \\
\text { Nanopartikel (nm) }\end{array}$ & $\begin{array}{c}\text { Indeks } \\
\text { Polidispersitas }\end{array}$ & $\begin{array}{c}\text { Zeta } \\
\text { potensial } \\
(\mathbf{m V})\end{array}$ & $\begin{array}{c}\text { Efisiensi } \\
\text { Penjeratan (\%) }\end{array}$ & $\begin{array}{c}\text { Loading } \\
\text { Capacity (\%) }\end{array}$ \\
\hline- & $114,27 \pm 11,24$ & $0,269 \pm 0,118$ & $-0,10$ & - & - \\
\hline 7,5 & $121,47 \pm 1,167$ & $0,177 \pm 0,069$ & $-0,65$ & $90,39 \pm 0,157$ & $18,076 \pm 0,030$ \\
\hline 15 & $174,23 \pm 13,94$ & $0,185 \pm 0,052$ & $-1,62$ & $90,54 \pm 0,098$ & $30,18 \pm 0,036$ \\
\hline
\end{tabular}




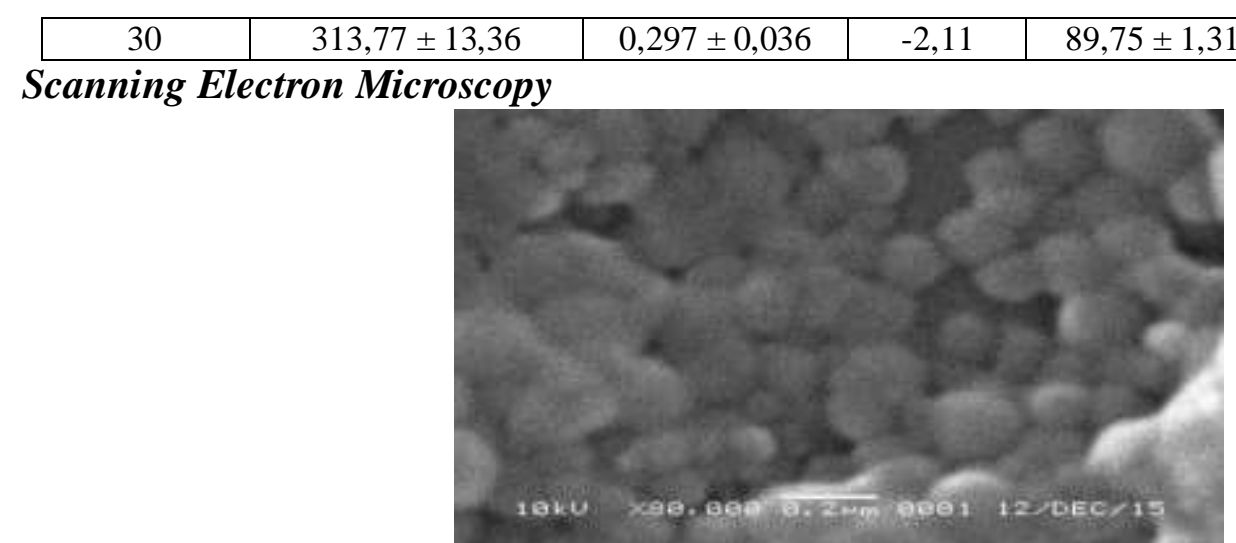

Gambar 1. Pengamatan SEM nanopartikel BSA-silimarin perbesaran 80.000x

(C)Fotomikrograf SEM di atas menunjukkan bahwa nanopartikel BSAsilimarin memiliki bentuk morfologi berupa partikel sferis, walaupun terlihat kohesif karena sifat adesif dari BSA.

\section{Spektroskopi Inframerah}

Prosedur

spektroskopi

pengujian inframerah analisis untuk nanopartikel BSA, nanopartikel BSASilimarin, BSA dan silimarin tidak dilakukan penggerusan, hal ini bertujuan untuk menjaga keutuhan sistem. Dari hasil overlay menunjukkan bahwa pita-pita spektrum antara Nanopartikel BSA-
Silimarin mirip dari nanopartikel BSA, dan tidak terlihat lagi puncak dari silimarin. Hal ini menunjukkan bahwa silimarin berada dalam nanopartikel sehingga tidak terdeteksi. Untuk memastikan hasil tersebut, maka dilakukan karakteristik selanjutnya yaitu Difraktometri Sinar-X, dan Analisis Termal DSC.

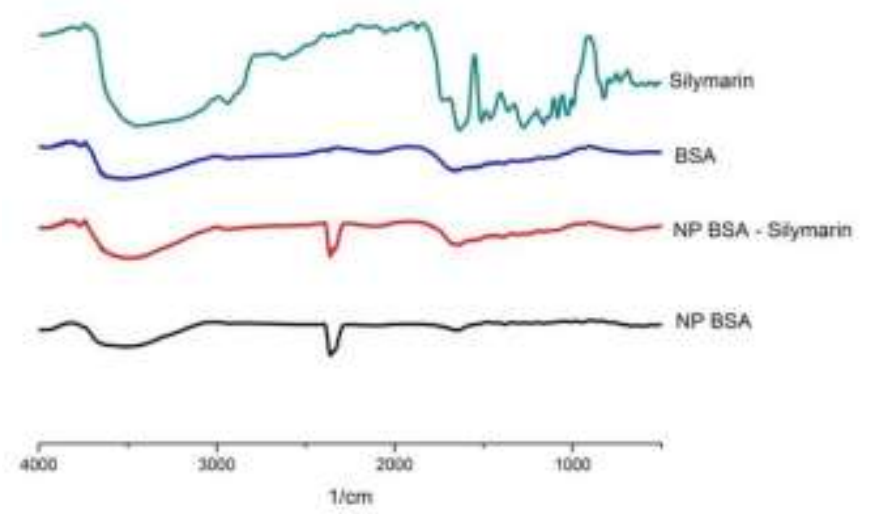

Gambar 2. Spektrum Inframerah Nanopartikel BSA, Nanopartikel BSA-Silimarin, BSA, \& Silimarin

\section{Difraktrometri Sinar-X}

Difraktogram dari Silimarin terlihat puncak puncak difraksi yang tajam dan kuat, dan juga terdapat puncak-puncak dengan intensitas yang rendah. Difraktogram nanopartikel BSA-silimarin terlihat puncak difraksi sinar-X yang lebar, ini menunjukkan bahwa nanopartikel BSA-silimarin bersifat amorf $(77,3 \%)$. Difraktogram nanopartikel BSA-silimarin menunjukkan adanya peningkatan puncak difraksi pada $\theta$ yang ke 10, dibandingkan 
dari difraktogram nanopartikel BSA. Dari hasil overlay, difraktogram nanopartikel BSA-silimarin menunjukkan pola yang sama dengan difraktogram dari BSA dan nanopartikel BSA dibandingkan difraktogram dari silimarin, hal ini menunjukkan bahwa silimarin berada di dalam sistem nanopartikel BSA (Ding dkk., 2013).

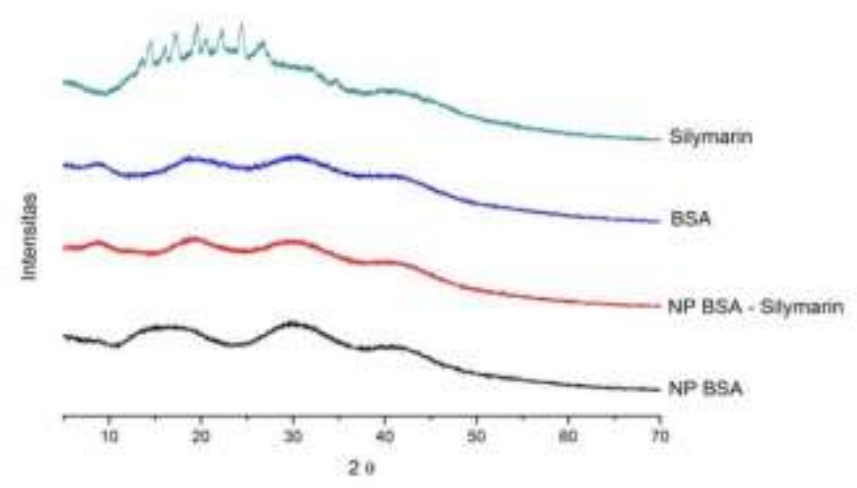

Gambar 3. X-ray difaktrogram Nanopartikel BSA, Nanopartikel BSA-Silimarin, BSA, \& Silimarin

\section{Analisis termal (DSC)}

Pada nanopartikel BSA-silimarin terdeteksi adanya $\mathrm{Tg}$ pada temperatur $28,25^{\circ} \mathrm{C}$, puncak endotermik pada $62,32^{\circ} \mathrm{C}$. Sedangkan pada BSA terdeteksi adanya $\mathrm{Tg}$ pada temperatur $34,51^{\circ} \mathrm{C}$ dan puncak endoterm pada temperatur $71,86^{\circ} \mathrm{C}$. Menurut Lai dkk. (2000), Tg pada suhu sekitar $30^{\circ} \mathrm{C}$ adalah sub $\mathrm{Tg}$ sedangkan pada temperatur yang lebih tinggi disebut $\mathrm{Tg}$. Nilai sub $\mathrm{Tg}$ dapat berhubungan dengan kandungan lembab dari sampel yang dianalisis dimana penurunan nilai tersebut berhubungan dengan peningkatan aktivitas air pada sampel. Terjadi penurunan $\mathrm{Tg}$ pada nanopartikel BSA dan Nanopartikel BSAsilimarin dibandingkan dengan $\mathrm{Tg}$ BSA nya. Hal ini menunjukkan kelembaban dari Nanopartikel yang terbentuk lebih tinggi karena pada pembuatan nanopartikel dengan teknik desolvasi menggunakan air sebagai pelarut dari BSA. Puncak endotermik dari Silimarin tertutupi oleh BSA dalam Nanopartikel BSA-Silimarin, hal ini mengindikasikan bahwa Silimarin terenkapsulasi oleh BSA.

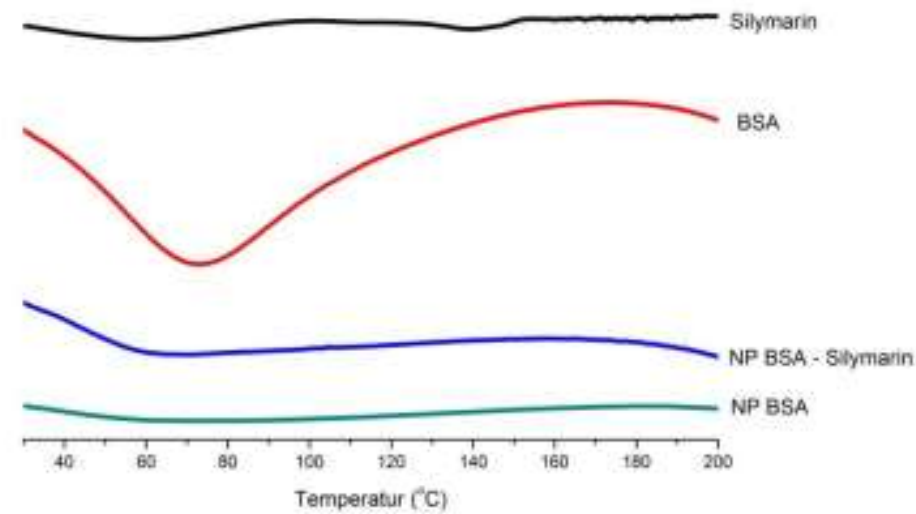

Gambar 4. Profil DSC dari Nanopartikel BSA, Nanopartikel BSA-Silimarin, BSA, 
\& Silimarin

Evaluasi Pelepasan Zat Aktif Secara In menit terlepas 16,63\%; dan pada menit ke Vitro

Pada umumnya, kecepatan pelepasan obat bergantung pada kelarutan, desorpsi permukaan, difusi melalui matriks polimer dan degradasi matriks nanopartikel (Mahapatro dan Singh, 2011). Dari Gambar 5 dapat dilihat jumLah Silimarin yang terlepas pada medium $\mathrm{HCl}$ (mensimulasikan cairan lambung) pada 15 menit pertama terlepas sebesar 5,40\%; kemudian berlanjut 30 menit 10, 96\%; 45

60 terlepas sebesar 21,89\%. Diharapkan silimarin tidak terlepas dalam cairan lambung. Hasil uji menunjukkan bahwa silimarin terlepas, meskipun $<25 \%$ setelah 1 jam. Sistem nanopartikel BSA-silimarin diharapkan terabsorpsi secara utuh. Akan tetapi jika diperhatikan dari ukurannya $(>100 \mathrm{~nm})$, sulit sistem ini bisa terabsorpsi melalui jalur paraseluler, sehingga pemberian oral perlu dipertimbangkan.

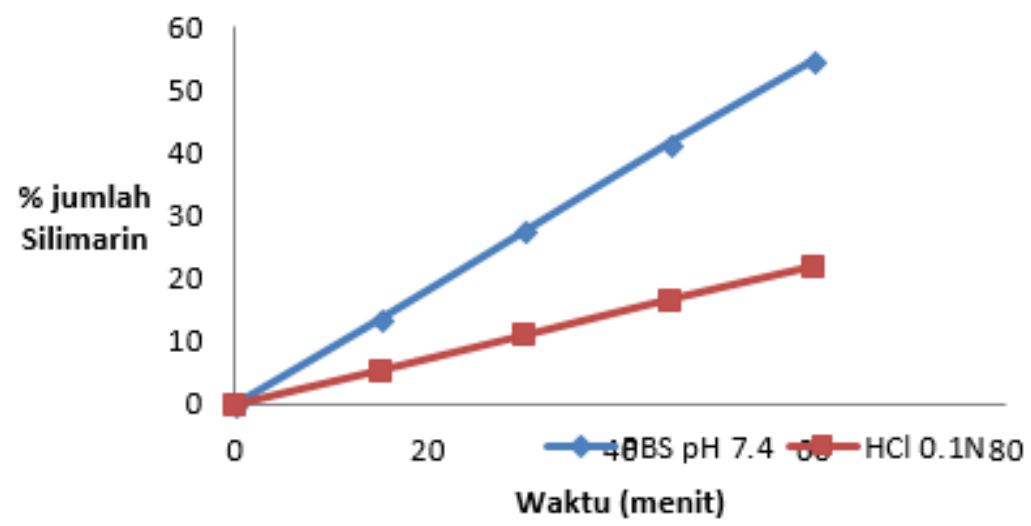

Gambar 5. Profil pelepasan in vitro dari Nanopartikel BSA-Silimarin

Tabel 2. Hasil Uji Pelepasan Silimarin

\begin{tabular}{|c|c|c|}
\hline \multirow{2}{*}{ Waktu (menit) } & \multicolumn{2}{|c|}{ JumLah Silimarin yang terlepas (\%) } \\
\cline { 2 - 3 } & PBS pH 7,4 & HCl 0,1 N \\
\hline 15 & $13,54 \pm 1,326$ & $5,4 \pm 3,239$ \\
\hline 30 & $27,55 \pm 2,39$ & $10,96 \pm 6,838$ \\
\hline 45 & $41,59 \pm 4,427$ & $16,93 \pm 8,052$ \\
\hline 60 & $54,84 \pm 5,916$ & $21,89 \pm 10,722$ \\
\hline
\end{tabular}

Alternatifnya adalah melalui rute intramuskular. Oleh karena itu, dilakukan juga uji pelepasan dalam medium PBS pH7,4 (simulasi dalam darah). Pada medium PBS pH 7,4 jumLah Silimarin yang terlepas pada menit ke 15 pertama adalah sebesar 13,54\%; 30 menit sebesar 27,55\%; pada menit ke 45 terlepas sebesar 41,59\%; dan pada menit ke 60 terlepas sebesar 54,84\%. Setelah 1 jam pemberian, Silimarin yang lepas sebesar 54,84\%, jumLah yang cukup besar jika sistem nanopartikel BSA-silimarin diinginkan untuk tujuan bertarget ke sel kanker. Jika waktu distribusi nanopartikel BSAsilimarin menuju ke sasaran kurang dari 30 menit, maka tujuan akumulasi sistem ini akan tercapai dan diharapkan setelah mencapai sel kanker, sistem akan mengalami endositosis diperantarai oleh reseptor spesifik BSA dan melepaskan silimarin intraseluler. Untuk membuktikan dugaan ini, perlu dilakukan kajian yang lebih mendalam. 


\section{SIMPULAN}

Nanopartikel BSA dengan teknik desolvasi menggunakan aseton berhasil mengenkapsulasi silimarin. Karakteristik sistem ini adalah memiliki ukuran partikel $174,23 \pm 13,94 \mathrm{~nm}$; indeks polidispersitas $0,185 \pm 0,052$; efisiensi penjeratan 90,54 \pm $0,098 \%$; loading capacity $30,18 \pm 0,036 \%$ dan zeta potensial $-1,62 \mathrm{mV}$. Hasil analisis menggunakan DSC, Difraktometri sinar-X, dan spektroskopi inframerah menunjukan bahwa silimarin berada di dalam sistem nanopartikel BSA.

\section{DAFTAR PUSTAKA}

Ding, D., X. Tang, X. Cao, J. Wu, A. Yuan Q. Qiao, J. Pan, J. Hu. 2014. Novel Self-assembly endows human serum albumin nanoparticles with an enhanced antitumor efficacy. American Association of Pharmaceutical Scientists. 5(1): 21322.

Lai, Y.C., P.H. Sung dan J.T. Chen, J.T. 2000. Evaluation of compability of rice strach and pectins by glass transition and sub-tg endotherms and the effect of compability on gel viscosity and water loss. Cereal Chem. 77(5): 544-550.

Langer, K., S. Balthasar, V. Vogel, N. Dinauer, H. Von Briesen dan Schubert, D. 2003. Optimization of the preparation process for human serum albumin (HSA) nanoparticles. International Journal of Pharmaceutics. 257. 169-180.

Mahapatro, A. dan D.K. Singh. 2011. Biodegradable nanoparticles are excellent vehicle for site directed invitro delivery of drugs and vaccines. Journal of Nanobiotechnology. 9(55): 1-11.

Snima, K.S., P. Arunkumar, R. Jayakumar, V.K. Lakshmanan. 2014. Silymarin encapsulated poly(D,L-lactic-coglycolic acid) nanoparticles: a prospective candidate for prostate cancer therapy. J. Biomed. Nanotechnol. 10: 559-570.

Yuan, A., J. Wu, C. Song, X. Tang, Q. Qiao, L. Zhao, G. Gong dan Y. Hu. 2013. A Novel Self-Assembly Albumin Nanocarrier for Reducing Doxorubicin-Mediated

Cardiotoxicity. Journal of Pharmaceutical Sciences. 102(5): 1626-1635. 